\section{Bernard Grant Sims}

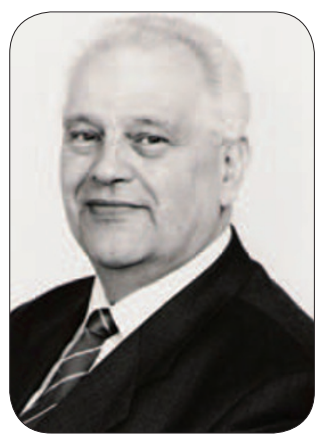

Bernard Sims died on 29 November 2006. Known affectionately as Bernie, he was the father figure of Forensic Odontology in the United Kingdom. Born in East London in 1931, he was educated at Raines Foundation Grammar School. In 1950 he was accepted at Queen Mary College, but his studies were interrupted by National Service in the Royal Navy, both at home and in the Far East, where he was awarded the United Nations Korean Medal.

Bernie resumed his studies at The London Hospital Medical College Dental School, obtaining his LDS in 1960 and his BDS in 1961 and, after a house job, went into general practice firstly in Hatton Garden and then in Canning Town. He immediately undertook forensic duties, on a voluntary basis, and by 1963 had enough experience to present a paper at an international meeting on Forensic Medicine in Amsterdam. This was followed over the next 30 years by more than 30 papers and chapters in medical, dental and legal textbooks. His own textbook, Forensic Odontology (1973), co-authored with Professor 'Taffy' Cameron, became an international standard.

Bernie's contribution to dentistry came at a price; he attended some of the worst mass disasters in the world, including the BA Trident plane crash at Heathrow in 1972 and the Lockerbie plane crash

\section{...his lectures were entertaining, compassionate and always instructive.}

in 1988; the King's Cross fire in 1987; the Moorgate train crash in 1975 and the sinking of the Marchioness Riverboat in 1989.

Despite all the horror, Bernie kept his compassion and his sense of humour.

He was a natural teacher, obtaining his first honorary lectureship in Forensic Odontology at the London in 1967 and becoming Senior Lecturer in 1975. In the 1990s he held three honorary senior lectureships all at the same time!

He lectured all over the world and his lectures were entertaining, compassionate and always instructive. He spoke at innumerable BDA groups, and in 2001 was awarded the MBE.

Almost single handed Bernie built forensic odontology into the essential place it has today. He taught a whole generation of dentists the importance of dental records as a means of identification and enthused many to follow in his footsteps.

Bernie Sims was a kind, unassuming man, with a wealth of stories to tell. He was universally respected and his many friends around the world will miss him. Bernie's beloved wife Gwen died in 2003, but he is survived by his daughter Jane.

S. Morganstein

\title{
William Norval Mason
}

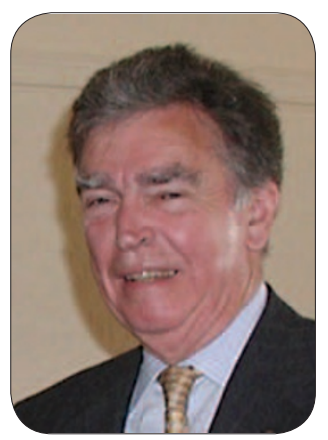

Dr 'Willie' Mason was born in Paisley on 10 October 1924 and educated at Paisley Grammar School and Glasgow Academy. He became a dental student at Glasgow in 1942, qualified Licentiate in Dental Surgery of the Royal College of Physicians and Surgeons in 1947 and obtained the Higher Dental Diploma in 1949.

After National Service in the Royal Air Force Dental Branch with the 2nd Tactical Air Force in Germany he returned to Paisley and started his own dental practice. About the same time he was appointed a Visiting Dental Surgeon at the Glasgow Dental Hospital and School.

In 1957, to enhance his experience and clinical skills, he spent a year in Canada at the University of Dalhousie in Novia Scotia and graduated Doctor of Dental Surgery in 1958.

On his return to Scotland he expanded his practice and developed his interest in clinical diagnosis and treatment planning. His main academic involvement was in Dental Radiology and he became Consultant at the Glasgow Dental Hospital and School. He gradually established one of the leading departments of Oral and Dental Radiology in the UK. He became President of the British Society of Dental and Maxillofacial Radiology in 1975 and was a prime mover in introducing specialist training programmes. He was recognised as a founder Diplomate in Dental Radiology in

\section{Whatever he did, he was always} looking for a constructive outcome...

1985, paving the way for career and consultant posts in Dental and Maxillofacial Radiology.

Away from his professional life he played golf off a handicap of 2, and also was an accomplished pianist. Latterly and especially in retirement, he enjoyed gardening and painting. A visit to his garden was a memorable and colourful experience as he demonstrated his latest products. He had always enjoyed the artistic aspects of dentistry and, in retirement, he found painting a natural progression, working mainly in pastels and oils. He exhibited his own work at Paisley Art Institute and in Glasgow.

Willie was a modest man who enjoyed life. He made many friends and loved company and conversation. Whatever he did, he was always looking for a constructive outcome and he enjoyed working with friends and colleagues to achieve it.

He is survived by his wife Lillias, his son George, daughter Sheena and three grandchildren, of whom he was very proud, and by his brother, Professor Sir David Mason. The family provided him with a happy home life and comforted him during the last few years of serious illness, which he fought with great courage, spirit and dignity. He died on 22 October 2006.

B. C. O'R 